\title{
Effects Of Manager Qualification On Firm Value
}

\author{
Sergiy Rakhmayil, Ryerson University, Toronto, Canada
}

Ayse Yuce, Ryerson University, Toronto, Canada

\begin{abstract}
This paper examines how $C E O$ and $C F O$ qualifications affect firm value. Our results indicate that companies with managers that have qualifications as prior senior managerial experience of $C E O s$, tenure of CEOs in the current position, MBA degrees of CFOs, and the university where the CFOs graduated are associated with higher company valuation, after controlling for firm age and industry effects.
\end{abstract}

Keywords: Firm Value, Managerial Qualifications, Human Capital

\section{INTRODUCTION}

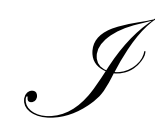

$\mathrm{n}$ the last two decades company executive compensation packages have increased tremendously. Large multinational companies compete with each other in paying higher and higher salaries and offering lucrative stock option packages to top managers. According to Murphy (1999), level of top executive compensation between 1992 and 1996 has increased 55\% from \$2.0 million to \$3.2 million. Many researchers ( Agrawal and Mandelker (1987), Agrawal and Walking (1994), Boschen and Smith (1995), Defusco, Johnson and Zorn (1990), Zhou (1990)) examined CEO and CFO compensation packages across industries and across nations. Taking into public sentiment administrators make companies disclose executive pay to the public. Although the researchers investigated effects of executive pay on shareholder wealth, the effect of managerial qualifications on long-term company value hasn't been investigated thoroughly.

This study explores whether or not managers with better education and better qualifications increase their firm value compared to their colleagues. We examine the relationship between qualifications and experiences of top management and firm market valuation using panel data for 490 companies between 1985 and 2005 . We investigate how education level and prior work experience of company CEOs and CFOs affect Tobin's Q values for companies in our sample. We gauge the education level by identifying whether or not executives have MBA degrees, and whether they graduated from a business school in top 25 of the Financial Times ranking list of business schools. Next, we measure work experience by tenure at the current position, and by documenting whether they had prior experience as a part of senior management team or as a partner in a law or accounting firm. We test for mean equality between Tobin's $Q$ values for firms where managers do have versus firms where managers do not have each of the outlined qualifications. Next, we analyze the relationship between managerial qualifications and Tobin's $\mathrm{Q}$ values using panel least squares estimation method with fixed period effects.

The influence of managerial skills on firm valuation has received limited attention from researchers. At present we are only aware of one study by Chemmanur and Paeglis (2005) who investigate the effect of managerial quality on IPO performance. A parallel stream of studies, for example Lucas (1978), Fama and French (1995), or Maksimovic and Phillips (2002), investigates how various firm characteristics affect market valuation of firms. At the same time many studies investigate how managerial skill affects mutual fund performance. In most cases the results are mixed, for example Switzer and Huang (2007) find significant cross sectional differences in fund mutual performance that are attributed to managerial qualifications, while Philpot and Peterson (2006) find little evidence that managerial qualifications add value. 
The present study adds to this literature in two ways. First, to the best of our knowledge this is the first study that investigates the relationship of qualifications and experiences of firm's top managers and firm valuation for mature (non-IPO) firms. Second, we investigate not only whether an executive has an MBA degree, but also in what university the CEOs and CFOs obtained education and how the place of study influences firm valuation.

The results of our empirical analysis suggest that managerial qualifications indeed have a bearing on firm valuation. First, we analyze the effect of each variable on Tobin's $Q$ values in univariate framework and discover that companies with CEOs and CFOs have MBA degrees and/or graduated from highly reputable business schools on average have significantly greater Tobin's $Q$ values compared with the companies whose managers do not have such qualifications. We also find evidence that prior senior management team experience of CFOs is associated with significantly higher Tobin's Q values for their firms. Second, we implement panel data estimation and find that managerial qualifications, such as senior experience of CEOs, tenure of CEOs in the current position, MBA degrees of CFOs, and the university where the CFOs graduated, significantly affect company valuation, after controlling for firm age and industry effects.

This paper is organized as follows. The next section describes the data set and section 3 outlines the hypotheses and methodology. Section 4 presents our findings, and is followed by the conclusion.

\section{DATA}

We include in our analysis panel data on companies in the S\&P 500, S\&P Midcaps, and S\&P Smallcaps indices between 1985 and 2005. The data on managerial qualifications are hand-collected from the investor information sections of company webpages in 2005. We collect information about tenure, education, and work experience for company CEOs and CFOs from their profiles. We also collect information and company age. Finally, we collect information on corporate governance, which includes whether or not the current chairman of the board of directors is also the CEO, the number of independent directors, and total number of directors on the board of each company. See for example Borokhovich et al (1996) for discussion of the benefits of outside directors in the board composition.

We require that both the CEO and CFO work for their companies for at least one year, because we expect some lag between the time when an executive is hired and the time he or she can make a tangible impact on company operations. We find 490 companies that satisfy all data requirements in terms of executive profile information, corporate governance, and financial performance variables.

We use the following variables to measure managerial qualifications. For both $\mathrm{CEO}$ and $\mathrm{CFO}$ we construct dummy variables CEOMBA and CFOMBA that indicate whether or not the executive has an MBA. The MBA degree should in theory help an executive better understand business situations and make better decisions. Variables CEOSCHOOL and CFOSCHOOL show whether the executive graduated from a university on the top 25 business school list from Financial Times ranking. More reputable business schools should provide better education and greater networking opportunities, and thus a graduate from such a school should be able to make better business decisions. Variables CEOPARTNER and CFOPARTNER indicate whether the corresponding executive was earlier a partner in a law or accounting firm, as such experience is valuable for top managers who have to routinely deal with legal and financial reporting issues that arise from company operations. Variable CEOTENURE and CFOTENURE specify the number of years in the current position, a greater number of years will mean that the individual has more experience on the job and this should translate into higher managerial qualifications. Finally, CEOSENIOREXP and CFOSENIOREXP show whether or not the executive has prior experiences as a part of senior management team in any company in his/her career. Chemmanur and Paeglis (2005) used a similar set of variables to assess the impact of managerial quality on the performance of IPOs.

Table I presents descriptive statistics for the managerial qualifications variables. We find 21 CEOs and 59 CFOs that have MBA degrees, as indicated by the sum of the variables CEOMBA and CFOMBA. Next, 4 CEOs and 13 CFOs had prior experience as a partner in a law or accounting firm, 75 CEOs and 77 CFOs graduated from a highly reputable business school. CEOTENURE varies from 4 to 44 years, and CFOTENURE ranges from 1 to 30 
years, indicating a higher turnover rate for CFOs. Finally, 373 CEOs and 408 CFOs has prior senior managerial experience, according to the information available on their profiles.

Table I: Managerial Qualifications

This table presents descriptive statistics for the measures of CEO and CFO qualifications. Variable CEO(CFO)MBA takes value of 1 if an executive has an MBA and zero otherwise. CEO(CFO)PARTNER takes value of 1 if an executive was earlier a partner in a law or accounting firm, and zero otherwise. Variable CEO(CFO)SCHOOL takes value of 1 if an executive graduated from a university on the top 25 business school list from Financial Times ranking, and zero otherwise. Variable CEO(CFO)TENURE specifies the number of years in the current position, as of December 2005.

Panel A: CEO Qualifications

\begin{tabular}{lccccc}
\hline & CEOMBA & CEOPARTNER & CEOSCHOOL & CEOSENIOREXP & CEOTENURE \\
\hline Mean & 0.0429 & 0.0082 & 0.1531 & 0.7612 & 11.5755 \\
Median & 0 & 0 & 0 & 1 & 9 \\
Maximum & 1 & 1 & 1 & 1 & 44 \\
Minimum & 0 & 0 & 0 & 0 & 4 \\
Std. Dev. & 0.2027 & 0.0901 & 0.3604 & 0.4268 & 7.6959 \\
Sum & 21 & 4 & 49 & 473 & 5672 \\
Observations & 490 & 490 & 490 & 490 \\
\hline
\end{tabular}

Panel B: CFO Qualifications

\begin{tabular}{lccccc}
\hline & CFOMBA & CFOPARTNER & CFOSCHOOL & CFOSENIOREXP & CFOTENURE \\
\hline Mean & 0.1204 & 0.0265 & 0.1571 & 0.8327 & 5.8633 \\
Median & 0 & 0 & 0 & 1 & 5 \\
Maximum & 1 & 1 & 0 & 1 & 30 \\
Minimum & 0 & 0 & 0.3643 & 0.3737 & 1 \\
Std. Dev. & 0.3258 & 0.1609 & 77 & 408 & 4.4707 \\
Sum & 59 & 13 & 490 & 490 & 2873 \\
Observations & 490 & 490 & & & 490 \\
\hline
\end{tabular}

Table II presents descriptive statistics for the variables that proxy for quality of corporate governance. In 382 out of 490 companies in our sample the CEOs are also Chairs of the board of directors, as indicated by the sum of variable CHAIRCEO. Next the degree of board independence measured by INDEPDIRPERCENT ranges from 0.22 to 0.93 with mean value of 0.7132 .

Next, we present industry composition of the sample in Table III. The most represented industry sector in our sample is Consumer Discretionary with 100 firms out of 490. The least represented sector is Telecommunication Services, which has only three firms that satisfies all data requirements.

In order to investigate the effect of managerial qualifications on firm performance and market valuation for the companies, we collect industry classification, balance sheet, and market valuation data from S\&P Compustat between 1985 and 2005. We collect data on Total Assets, Shareholders' Equity, Shares Outstanding, Price per Share, and Total Debt for the firms. We use these data to construct Tobin's Q as a measure of market valuation, we calculate it as follows: Tobin's $\mathrm{Q}=$ (Market value of equity +Book Value of Total Debt)/ Book Value of Total assets.

Table IV presents company age and market performance measures. For companies in our sample, Tobin's Q averages at 2.0635 and ranges from 0.2330 to 14.5920 . Median size as measured by Total Assets is $\$ 1,453.53$ million and it ranges from $\$ 11.42$ million to $\$ 750,507$ million. Finally, firm age varies from 3 to 222 years old, with mean age 45.4 years, and median size as measured by Total Assets is $\$ 9,894.0$ million. Thus, we have a sample of companies with very diverse market valuations, sizes, and histories. 


\section{Table II: Governance Proxies}

This table presents descriptive statistics for the company governance proxies. Variable CHAIRCEO takes value of 1 if the CEO is also the chairman of the board of directors for the company. Variable INDEPDIRPERCENT indicates the percentage of directors who are not corporate officers.

\begin{tabular}{ccc}
\hline & CHAIRCEO & INDEPDIRPERCENT \\
\hline Mean & 0.7796 & 0.7132 \\
Median & 1 & 0.73 \\
Maximum & 1 & 0.93 \\
Minimum & 0 & 0.22 \\
Std. Dev. & 0.4149 & 0.1439 \\
Sum & 382 & 349.49 \\
Observations & 490 & 490 \\
\hline
\end{tabular}

Table III: Industry Distribution

This table presents the industry distribution of firms in out sample.

\begin{tabular}{cc}
\hline Industry sector & Number of firms \\
\hline Materials & 39 \\
Consumer Discretionary & 100 \\
Consumer Staples & 23 \\
Health Care & 51 \\
Energy & 20 \\
Financials & 71 \\
Industrials & 83 \\
Information Technology & 73 \\
Telecommunication Services & 3 \\
Utilities & 27 \\
\hline Total: & 490 \\
\hline
\end{tabular}

\section{HYPOTHESES AND METHODOLOGY}

The quality of managers can affect financial performance and subsequent market valuation of companies in a variety of ways. Higher quality managers may be able to select better projects, and to implement them more effectively. Next, higher quality managers may be able to find a more appropriate combination of debt and equity in the firm's capital structure and thus lower company cost of capital. Finally, higher quality managers may be able to better convey (i.e. "certify") the intrinsic value of the firm to the capital markets. See for example Allen and Faulhaber (1989), Chemmanur (1993), Welch (1989), and Chemmanur and Paeglis (2005) for the discussion of this certification effect on IPO performance. Because of all the reasons outlined above, we expect that higher quality managers may improve market valuation of their firms.

We measure the unobservable managerial quality with the proxy variables that indicate whether not an executive has an MBA degree, graduated from a highly reputable business school, has extensive financial reporting and legal experience prior to becoming the company executive, has prior experience of working as a part of a senior management team, and tenure in a current position. We expect a positive relationship between each measure of the managerial quality and market valuation. 


\section{UNIVARIATE ANALYSIS}

To examine the link between managerial quality and company valuation we first compute Tobin's $Q$ annual averages for firms where CEOs or CFOs exhibit certain qualifications and compare them with the Tobin's Q annual averages for firms where CEOs or CFOs do not have such qualifications. In particular, we separate firms based on whether their CEOs or CFOs have MBA degrees, graduated from Financial Times top 25 business schools, have experience as a partner on a law or accounting firms, or have senior management team experience prior to becoming the CEO or CFO. as follows:

Next, we use seemingly unrelated regressions (SUR) method to estimate the system of equations specified

$$
\left\{\begin{array}{l}
Q_{t, D=0}=c(1)+\varepsilon_{1, t} \\
Q_{t, D=1}=c(2)+\varepsilon_{2, t}
\end{array}\right.
$$

where $\mathrm{Q}_{t, \mathrm{D}=0}$ is average Tobin's $\mathrm{Q}$ value in year $\mathrm{t}$ across companies where the executive in question (CEO or CFO) does not have the qualification (i.e. CEOMBA=0), $\mathrm{Q}_{\mathrm{t}, \mathrm{D}=1}$ is average Tobin's $\mathrm{Q}$ value in year $\mathrm{t}$ across companies where the executive in question (CEO or CFO) does have the qualification (i.e. CEOMBA=1), c(1)and (2) are constants and $\varepsilon_{1, \mathrm{t}}$ and $\varepsilon_{2, \mathrm{t}}$ are regression residuals. We estimate two regressions on the mean for firms with and without a given qualification, and the SUR method allows us to directly test using Wald test whether c(1) equals to $\mathrm{c}(2)$. We expect that if higher quality managers indeed improve firm investments, financing, operations, and investor recognition, then it should be the case that $\mathrm{c}(2)>\mathrm{c}(1)$.

\section{MULTIVARIATE ANALYSIS}

To test the relationship between managerial quality and company valuation we estimate the flowing equation using panel least squares method with fixed period effects and White's correction for heteroskedasticity.

$$
\begin{aligned}
Q_{i, t} & =\beta_{0}+\beta_{1} \text { CEOMBA }_{\mathrm{i}}+\beta_{2} \text { CEOSCHOOL }_{\mathrm{i}}+\beta_{3} \text { CEOPARTNER }_{\mathrm{i}}+ \\
& +\beta_{4} \text { CEOSENIOREXP }_{i}+\beta_{5} \ln \left(\text { CEOTENURE }_{i, t}\right)+ \\
& +\beta_{6} \text { CFOMBA }_{\mathrm{i}}+\beta_{7} \mathrm{CFOSCHOOL}_{\mathrm{i}}+\beta_{8} \mathrm{CFOPARTNER}_{\mathrm{i}}+ \\
& +\beta_{9} \text { CFOSENIOREXP }_{i}+\beta_{10} \ln \left(\text { CFOTENURE }_{i, t}\right)+ \\
& +\beta_{12} \ln \left(\text { COMPANYAGE }_{\mathrm{i}, \mathrm{t}}\right)+\beta_{13} \mathrm{CHAIRCEO}_{\mathrm{i}}+\beta_{14} \text { INDEPDIRPERCENT }_{\mathrm{i}}+ \\
& +\sum_{j=1}^{9} \lambda_{j} \text { IndustryDummy }_{i, j}+\varepsilon_{i}
\end{aligned}
$$

where CEOMBA and CFOMBA $=1$ when an executive has an MBA and zero otherwise, CEOSCHOOL and CFOSCHOOL $=1$ when an executive graduated from the top 25 Financial Times business school and zero otherwise, CEOPARTNER and CFOPARTNER $=1$ when an executive has previous experience as a partner in an accounting or law firm and zero otherwise, CEOSENIOREXP and CFOSENIOREXP $=1$ when an executive has previous experience as a part of top management team in any company and zero otherwise, CEOTENURE and CFOTENURE is the number of years the officer worked in current position. The other independent variables are not related to the quality of management and are used as control variables for other aspects of firm quality. COMPANYAGE is the number of years since the company started operations or was incorporated, whichever occurred first. CHAIRCEO $=1$ when the CEO is also the chairman of the board and 0 otherwise, and INDEPDIRPERCENT is the percentage of independent directors on the board. 
Figure I

This figure presents the time trajectories of annual cross sectional mean values for Tobin's Q values for firms whose CEOs and CFOs have MBA and SCHOOL dummy variables equal to 0 or 1.

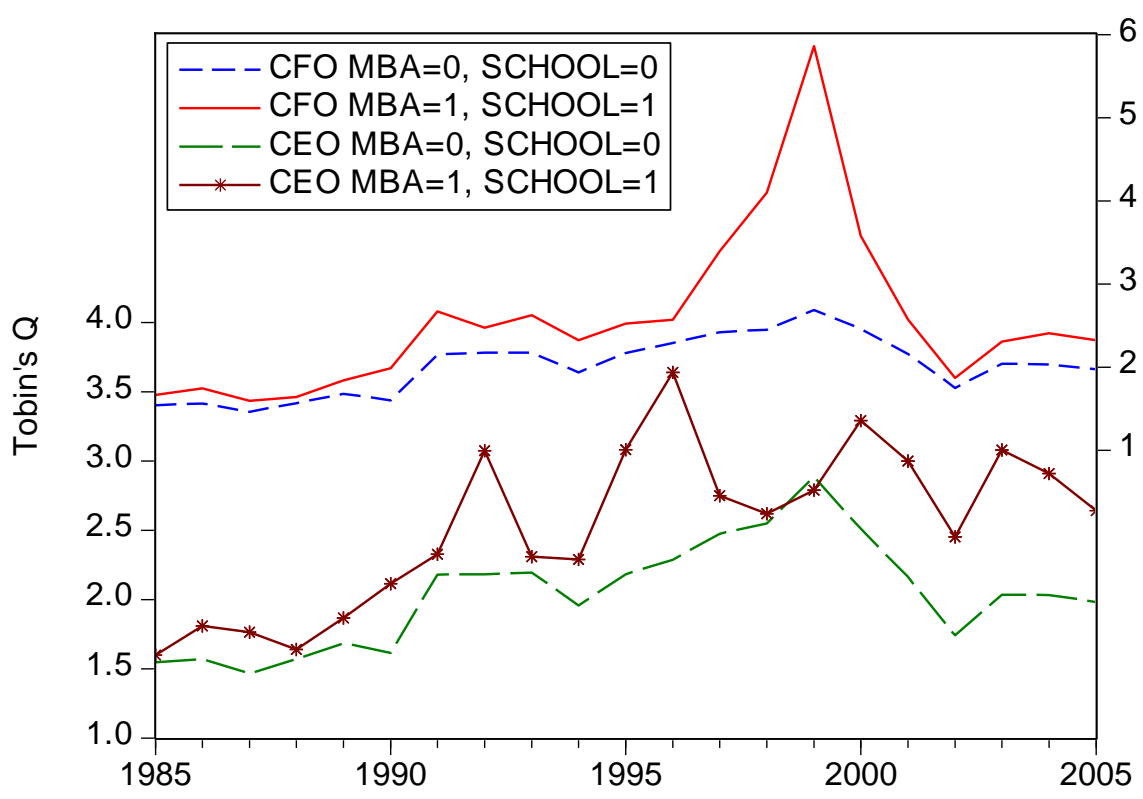

\section{EMPIRICAL RESULTS}

Figure I presents time trajectories of annual averages for Tobin's Q values for firms with CEOs (CFOs) have both MBA and SCHOOL dummy variables equal to 0 or 1 . A casual inspection of the graphs reveals that in almost all years higher average Tobin's Q values were displayed by companies whose managers have an MBA and graduated from a highly reputable business school. Thus, it appears that companies managed by better educated managers were indeed valued higher.

To formally examine the relationship between managerial qualifications and firm valuation we estimate system (1) for the CEO's and CFO's: MBA\&SCHOOL, MBA, SCHOOL, PARTNER, and SENEXP and test whether intercepts for both equations are equal. The test results are presented in Table 5 show that for variables CEOMBA $\times$ CEOSCHOOL, CFOMBA $\times$ CFOSCHOOL, CEOMBA, CFOMBA, CEOSCHOOL, CFOSCHOOL, and CFOSENEXP the parameter estimates are as predicted, $c(2)>c(1)$, and significantly different from each other. In particular, for variables CEOSCHOOL we have $c(1)=2.0329$, which is less than $c(2)=2.1350$, as predicted. The chi square statistic for the coefficient equality test is 13.7153 and highly significant. For variable CEOSENEXP the coefficient estimates are as predicted but we cannot reject the null hypothesis of coefficient equality $c(1)=c(2)$.

For variables CEOPARTNER and CFOPARTNER the coefficient estimates are the opposite from predicted, it appears that companies where a CEO or a CFO has never been a partner on average are valued higher. We hypothesize that this result may be due to a small number of companies where the executives have such experience: in our sample there are only 4 companies where the CEO was a partner and only 13 companies where the CFO was 


\section{Table IV: Company Performance}

This table presents descriptive statistics for the company characteristics. They include Tobin's Q, Total Assets, and Company Age. Tobin's $Q=$ (Market value of equity +Book Value of Total Debt)/ Book Value of Total assets. Descriptive statistics for Tobin's Q and Total Assets are calculated using panel data between 1985 and 2005. Company Age is reported as of December 2005.

\begin{tabular}{cccc}
\hline & TOBINS Q & Total Assets & Company Age \\
\hline Mean & 2.0635 & 9427.49 & 45.4 \\
Median & 1.6095 & 1453.53 & 32 \\
Maximum & 14.5920 & 750507.00 & 222 \\
Minimum & 0.2330 & 11.42 & 3 \\
Std. Dev. & 1.4070 & 38612.51 & 37.33 \\
Obs. & 2073 & 2073 & 490 \\
\hline
\end{tabular}

Table V: Univariate Analysis

This table presents estimation results for the system of equations (1). We estimate two regressions on the mean for firms with and without a given managerial qualification using the SUR method, and directly test using Wald test whether $\mathrm{c}(1)$ equals to $\mathrm{c}(2)$.

\begin{tabular}{|c|c|c|c|c|c|}
\hline & $\begin{array}{c}\text { CEOMBAX } \\
\text { CEOSCHOOL }\end{array}$ & CEOMBA & CEOSCHOOL & CEOPARTNER & CEOSENEXP \\
\hline $\mathrm{C}(1)$ & $\begin{array}{c}2.0388 * * * \\
(24.831)\end{array}$ & $\begin{array}{c}2.0447 * * * \\
(24.606)\end{array}$ & $\begin{array}{c}2.0329 * * * \\
(24.745)\end{array}$ & $\begin{array}{c}2.0505 * * * \\
(24.870)\end{array}$ & $\begin{array}{c}2.0426 * * * \\
(27.039)\end{array}$ \\
\hline $\mathrm{C}(2)$ & $\begin{array}{c}2.5263 * * * \\
(20.429)\end{array}$ & $\begin{array}{c}2.1563 * * * \\
(27.264)\end{array}$ & $\begin{array}{c}2.1350 * * * \\
(24.602)\end{array}$ & $\begin{array}{c}1.8083 * * * \\
(19.411)\end{array}$ & $\begin{array}{c}2.0498 * * * \\
(23.969)\end{array}$ \\
\hline Wald $C(1)=C(2)$ & $32.4263 * * *$ & $3.7907 *$ & $13.7153 * * *$ & $9.2481 * * *$ & 0.0654 \\
\hline & $\begin{array}{c}\text { CFOMBA } \\
\text { CFOSCHOOL }\end{array}$ & CFOMBA & CFOSCHOOL & CFOPARTNER & CFOSENEXP \\
\hline $\mathrm{C}(1)$ & $\begin{array}{c}2.0129 * * * \\
(26.828)\end{array}$ & $\begin{array}{c}2.0146 * * * \\
(27.043)\end{array}$ & $\begin{array}{c}2.0269 * * * \\
(27.096)\end{array}$ & $\begin{array}{c}2.0532 * * * \\
(24.652)\end{array}$ & $\begin{array}{c}1.8158 * * * \\
(34.491)\end{array}$ \\
\hline $\mathrm{C}(2)$ & $\begin{array}{c}2.5751 * * * \\
(12.158)\end{array}$ & $\begin{array}{c}2.2998 * * * \\
(15.035)\end{array}$ & $\begin{array}{c}2.1570 * * * \\
(17.084)\end{array}$ & $\begin{array}{c}1.8600 * * * \\
(27.764)\end{array}$ & $\begin{array}{c}2.0985 * * * \\
(23.250)\end{array}$ \\
\hline Wald $C(1)=C(2)$ & $13.8411 * * *$ & $9.3906 * * *$ & $4.9540 * *$ & $8.3685 * * *$ & $25.1354 * * *$ \\
\hline
\end{tabular}

*** indicates $1 \%$ significance, $* *$ indicates $5 \%$ significance, $*$ indicates $10 \%$ significance 
Table VI: Multivariate Analysis

This table presents estimation results for equation (2) using panel least squares method with fixed period effects and White's correction for heteroskedasticity.

\begin{tabular}{|c|c|c|c|c|c|c|c|}
\hline Constant & CEOMBA & $\begin{array}{c}\text { CEO } \\
\text { SCHOOL } \\
\end{array}$ & CEOPARTNER & $\begin{array}{c}\text { CEO } \\
\text { SENIOREXP } \\
\end{array}$ & CEOTENURE & COMPANYAGE & \\
\hline $\begin{array}{c}0.772 * * * \\
(3.710)\end{array}$ & $\begin{array}{c}0.008 \\
(0.071) \\
\end{array}$ & $\begin{array}{c}0.031 \\
(0.647) \\
\end{array}$ & $\begin{array}{c}0.143 \\
(0.785) \\
\end{array}$ & $\begin{array}{l}0.088^{*} \\
(1.779) \\
\end{array}$ & $\begin{array}{c}0.113^{* * * *} \\
(4.134)\end{array}$ & $\begin{array}{c}0.019 \\
(1.162) \\
\end{array}$ & \\
\hline & CFOMBA & $\begin{array}{c}\text { CFO } \\
\text { SCHOOL }\end{array}$ & CFOPARTNER & $\begin{array}{c}\text { CFO } \\
\text { SENIOREXP }\end{array}$ & CFOTENURE & CHAIRCEO & $\begin{array}{l}\text { INDEPDIR } \\
\text { PERCENT }\end{array}$ \\
\hline & $\begin{array}{l}0.243 * \\
(1.947) \\
\end{array}$ & $\begin{array}{c}0.473 * * * \\
(3.367)\end{array}$ & $\begin{array}{c}0.033 \\
(0.523) \\
\end{array}$ & $\begin{array}{c}0.001 \\
(0.024) \\
\end{array}$ & $\begin{array}{c}0.005 \\
(0.168) \\
\end{array}$ & $\begin{array}{c}0.032 \\
(0.731) \\
\end{array}$ & $\begin{array}{c}-0.189 \\
(-1.318) \\
\end{array}$ \\
\hline Materials & $\begin{array}{c}\text { Consumer } \\
\text { Discretionary }\end{array}$ & $\begin{array}{c}\text { Consumer } \\
\text { Staples }\end{array}$ & Health Care & Energy & & & \\
\hline $\begin{array}{c}0.500 * * * \\
(4.944)\end{array}$ & $\begin{array}{c}0.914 * * * \\
(8.600)\end{array}$ & $\begin{array}{c}1.305 * * * \\
(8.598)\end{array}$ & $\begin{array}{c}1.823 * * * \\
(9.534) \\
\end{array}$ & $\begin{array}{c}0.539 * * * \\
(3.850)\end{array}$ & & & \\
\hline & & & & & & \multicolumn{2}{|c|}{ Model characteristics } \\
\hline Financials & Industrials & $\begin{array}{l}\text { Information } \\
\text { Technology }\end{array}$ & Utilities & & & $\begin{array}{l}\text { Total (unbalanced) } \\
\text { observations: }\end{array}$ & 2071 \\
\hline $0.238 * * *$ & $1.123 * * *$ & $1.473 * * *$ & 0.188 & & & Adjusted R2 & 0.1772 \\
\hline$(2.115)$ & $(6.070)$ & $(6.279)$ & $(1.555)$ & & & Akaike info criterion & 3.3470 \\
\hline & & & & & & Log likelihood & -3422.784 \\
\hline & & & & & & F-statistic & 11.615 \\
\hline Period fixed $(\mathrm{d} t$ & variables):YES & & & & & Prob(F-statistic) & 0.0000 \\
\hline
\end{tabular}


a partner in a law or accounting firm. In addition, this result may be due to the fact that univariate analysis ignores other factors that may be contributing to market valuation. To summarize, most of the evidence uncovered by univariate analysis points that companies run by managers with higher qualifications tend to also have higher market valuations.

Table VI presents the results of multivariate analysis. Examination of estimation results for equation (2) underscores that firms with more qualified top management have also higher market valuation as measured by Tobin's Q. In particular, we discover that firms have significantly higher Tobin's Q if they have CEOs who have prior senior managerial experience, CEOs who served longer in the current position, and CFOs who have MBA degrees and who graduated from a top business school. For example, the parameter estimate for variable CEOSENIOREXP is 0.088 and is significant at $10 \%$ level with the corresponding $\mathrm{t}$-value of 1.779 . The coefficients for CFOMBA and CFOSCHOOL are also significant at $10 \%$ and $1 \%$, respectively.

We find that for equation (2) the coefficient estimates for both CEOPARTNER and CFOPARTNER variables are positive, as predicted, although they are not statistically significant. It is possible that our earlier findings for this variable given by system (1) estimates are driven by limitations of the univariate analysis. Overall, evidence from multivariate analysis presented in Table VI once again suggests that companies whose managers have higher qualifications are valued more than the companies whose managers do not have such qualifications. We argue that higher firm valuation is a result of superior managerial skills employed by better educated and more experienced executives.

\section{CONCLUSION}

This study examines the relationship between qualifications of top management and firm market valuation. We study how education and work experience of company CEOs and CFOs affect Tobin's Q values for companies. We compare average Tobin's $Q$ values for firms where managers have qualifications and experiences versus firms where managers do not have them. We also analyze the relationship between managerial qualifications and Tobin's $Q$ values using panel least squares estimation.

Our analysis unveils a number of interesting results. We find that companies whose CEOs and CFOs have MBA degrees and/or graduated from highly reputable business schools on average have significantly higher firm valuations compared with the companies whose managers do not have these qualifications. We also find that prior senior management team experience of CFOs is associated with significantly higher Tobin's Q values for their firms. Finally, we find that such managerial qualifications as senior experience of CEOs, tenure of CEOs in the current position, MBA degrees of CFOs, and the university where the CFOs graduated significantly improve company valuation, after controlling for firm age and industry effects.

These results support human capital theory that superior qualifications and experience will improve manager's productivity by helping them to choose better investment projects and to implement them more effectively. They are also in line with predictions of certification theory (i.e. Chemmanur (1993) that higher quality managers help reduce information asymmetry and better convey the intrinsic value of the firm to the capital markets. Overall, we find positive effect of top managerial qualifications on firm valuation.

\section{ABOUT THE AUTHORS}

Dr. Sergiy Rakhmayil is an assistant professor of finance at Ryerson University. He specializes in asset pricing and international finance.

Dr. Ayse Yuce is a professor of finance at Ryerson University. She has several publications in finance journals as well as two books. As an emerging market expert, Dr Yuce gave speeches at IMF and World Bank on Eastern European Stock Markets. 


\section{REFERENCES}

1. Allen, F., Faulhaber, G., 1989, Signaling by underpricing in the IPO market, Journal of Financial Economics 23, 303-323.

2. Agrawal, A., and Mandelker, G., 1987, Managerial Incentives and Corporate Investment and Financing Decisions, Journal of Finance, 42 (4), 823-37

3. Agrawal, A., and Walkling, R., 1994, Executive Careers and Compensation Surrounding Takeover Bids, Journal of Finance, 49 (3), 985-1014

4. Borokhovich, K., Parrino, R., and Trapani, T., 1996, Outside Directors and CEO Selection, The Journal of Financial and Quantitative Analysis, Vol. 31, No. 3, pp. 337-355

5. Boschen, J., and Smith, K., 1995, You Can Pay Me Now and You Can Pay Me Later: The Dynamic Response of Executive Compensation to Firm Performance, Journal of Business, 68(4), 577-608

6. Chemmanur, T., 1993, The Pricing of Initial Public Offerings: A Dynamic Model with Information Production, Journal of Finance 48, 285-304

7. Chemmanur, T., and Paeglis, I., 2005, Management Quality, Certification, and Initial Public Offerings, Journal of Financial Economics 76, 331-368

8. DeFusco, R., Johnson, R., and Zorn, T., 1990, The Effect of Executive Stock Option Plans on Stockholders and Bondholders,Journal of Finance, 50 1029-1057

9. Fama, E., and French, K., 1995, Size and Book-to-Market Factors in Earnings and Returns, Journal of Finance, 50 131-155

10. Lucas, R., 1978, On the Size Distribution of Business Firms, Bell Journal of Economics 9, No. 2 508-523.

11. Maksimovic, V., and Phillips, G., 2002, Do Conglomerate Firms Allocate Resources Inefficiently Across Industries? Theory and Evidence, Journal of Finance, 52, Issue 2. 721-767.

12. Murphy, KJ. "Executive Compensation," in Orley Ashenfelter and David Card (eds.), Handbook of Labor Economics, Vol. 3b, Elsevier Science North Holland (1999), Chapter 38: 2485-2563.

13. Philpot, J., and Peterson, C., 2006, Manager Characteristics and Real Estate Mutual Fund Returns, Risk and Fees, Managerial Finance, 32, 988-996

14. Switzer, L., and Huang, Y., 2007, How Does Human Capital Affect the Performance of Small and Mid-cap Mutual Funds?, Journal of Intellectual Capital 8, 666-681

15. Welch, I., 1989, Seasoned Offerings, Imitation Costs, and the Underpricing of Initial Public Offerings, Journal of Finance, 44, 421-449

16. Zhou, X., 2000, CEO Pay, Firm Size, and Corporate Performance: Evidence from Canada, Canadian Journal of Economics, 33 (1), 213-251 